\title{
Additional new insights into Biometeorology
}

\author{
Simon N. Gosling ${ }^{1}$
}

Received: 23 August 2017 / Revised: 15 November 2017 / Accepted: 15 November 2017 / Published online: 21 December 2017 (C) ISB 2017

This is the second Special Issue published in International Journal of Biometeorology that is devoted to presenting research conducted by members of the Students and New Professionals (SNP) group of the International Society of Biometeorology (ISB).

The first SNP Special Issue was published in 2014 (Gosling 2014), following a meeting 3 years earlier at the 19th International Congress of Biometeorology (ICB) in Auckland, New Zealand, at which several members of the SNP identified potential articles to include in a Special Issue. That issue included 17 articles and to date, it has attracted over 300 citations (according to Google Scholar). The first Special Issue was a springboard for a number of research activities initiated by the SNP, including the development of an online interactive glossary of biometeorological terms that stemmed from the first glossary for Biometeorology that appeared in the issue (Gosling et al. 2014), and the organisation of a workshop on the Spatial Synoptic Classification (SSC) in Vindeln, Sweden. The latter followed a review presented by Hondula et al. (2014) that identified novel opportunities for the application of the SSC to new regions of the globe, and it has resulted in a comprehensive review of the role of the SSC in interdisciplinary research (Dixon et al. 2016).

On the back of the successful first Special Issue, submissions to a second Special Issue were solicited at the 20th ICB in 2014, in Cleveland, U.S. The issue includes 11 research articles that cover many of the topics central to the field of Biometeorology, including animals, air pollution, climate and health and tourism. Furthermore, the articles mirror the SNP's efforts to enhance the equality and diversity of its membership, with lead authors representing institutions from Australia, Czech Republic, Germany, Nigeria, Poland and the U.S., and over a third of the lead authors are women.

Simon N. Gosling

simon.gosling@nottingham.ac.uk

1 School of Geography, University of Nottingham, Nottingham, UK
The first article in the issue is a Short Communication in which Lees et al. (2017) explore the validity of using infrared thermography technology to measure the core body temperature of Black Angus steers. The second article also covers animal biometeorology - Sinkalu and Ayo (2016) describe an experiment in which they investigate the ability of co-administration of retinol, ascorbic acid and $\alpha$-tocopherol to prevent heat stress in pullets. The Special Issue includes one article on air pollution, by Lokys et al. (2017), in which the authors assess the suitability of the Common Air Quality Index (CAQI), the Multi Pollutant Index (MPI) and the Universal Thermal Climate Index (UTCI) to describe associations between air quality, thermal stress and morbidity in western Germany.

There then follows a series of five articles on climate and health, which is the most popular topic covered by the Special Issue-unsurprising when considering that over the past 60 years, the three most common words included in the title of articles published in International Journal of Biometeorology have been 'effect(s)', 'temperature' and 'climate', respectively (Sheridan and Allen 2017). The first two climate and health articles in the Special Issue are focussed principally on the effects of heat: Walikewitz et al. (2015) compare indoor and outdoor estimates of UTCI and air temperature in the summer in Berlin (Germany) and discuss the implications for thermal stress; and Hardin and Vanos (2017) assess associations between different land surface types and changes in radiation absorbed by humans. Both heat and cold effects are considered by Allen and Sheridan (2015), in their assessment of relationships between extreme temperature events and all-cause mortality across 50 locations in the U.S. The last two articles on climate and health employ synoptic-scale weather classification schemes: Zhao et al. (2017) investigate associations between cold season weather types and human influenza across 79 U.S. cities; and Urban and Kyselý (2015) investigate the relationship between summer season cardiovascular mortality and weather types in Prague, Czech Republic.

The last three research articles are on the topic of climate and tourism. Two of these explore public perceptions of the thermal environment: Lam et al. (2016) compare perceptions of 
thermal conditions between locals and visitors to the Royal Botanic Garden in Melbourne, Australia; and LindnerCendrowska and Błażejczyk (2016) explore seasonal variability of weather perceptions among people spending time outdoors for tourism and recreation in Warsaw, Poland. The final article in the Special Issue assesses the applicability of synoptic-scale weather classification to predict visitor attendance at zoological parks in Atlanta and Indianapolis, U.S. (Perkins 2016).

In November 2017, Mr Hamed Mehdipoor (University of Twente, Netherlands) was voted-in as the new Chair of the SNP. The last article in this Special Issue is a news item prepared by the former Chair (Vanos 2015), which was first published online in March 2015, shortly after Dr Vanos became the Chair. A similar news item from Mr Mehdipoor is expected in a forthcoming issue in 2018.

The SNP continues to be a thriving section of the ISB, with almost 70 active members (Vanos 2017). The articles included in this Special Issue are testament to the SNP's broad research specialisms and its members' devotion to high quality research. The ISB is committed to supporting the continuing professional development of its SNP members, not least because the SNP represents the future of the ISB. The two former Chairs of the SNP, Dr Simon Gosling (Gosling 2010) and Dr Jennifer Vanos (Vanos 2015), are now ISB councillors for Europe and the USA, respectively, for instance. The Society, through its journal, International Journal of Biometeorology, which is now in its 60th year (Sheridan and Allen 2017), will continue to build upon the foundations of support for, and recognition of, the SNP.

\section{References}

Allen MJ, Sheridan SC (2015) Mortality risks during extreme temperature events (ETEs) using a distributed lag non-linear model, Int $\mathrm{J}$ Biometeorol, https://doi.org/10.1007/s00484-015-1117-4

Dixon PG, Allen M, Gosling SN, Hondula DM, Ingole V, Lucas R, Vanos J (2016) Perspectives on the Synoptic Climate Classification and its Role in Interdisciplinary Research. Geography Compass 10:147-164. http://dx.doi.org/10.1111/ gec3.12264

Gosling SN (2010) ISB News January 2010. Int J Biometeorol 54:113-113. https://doi.org/10.1007/s00484-009-0297-1

Gosling SN (2014) New insights into biometeorology. Int J Biometeorol 58(2):101-102. https://doi.org/10.1007/s00484-014-0793-9

Gosling SN, Bryce EK, Dixon PG, Gabriel KMA, Gosling EY, Hanes JM, Hondula DM, Liang L, Bustos Mac Lean PA, Muthers S,
Nascimento ST, Petralli M, Vanos JK, Wanka ER (2014) A glossary for biometeorology. Int J Biometeorol 58(2):277-308. https://doi. org/10.1007/s00484-013-0729-9

Hardin AW, Vanos JK (2017) The influence of surface type on the absorbed radiation by a human under hot, dry conditions, Int $\mathrm{J}$ Biometeorol, https://doi.org/10.1007/s00484-017-1357-6

Hondula DM, Vanos JK, Gosling SN (2014) The SSC: a decade of climate-health research and future directions. Int J Biometeorol 58(2): 109-120. https://doi.org/10.1007/s00484-012-0619-6

Lam CKC, Loughnan M, Tapper N (2016) Visitors' perception of thermal comfort during extreme heat events at the Royal Botanic Garden Melbourne, Int J Biometeorol, https://doi.org/10.1007/s00484-015$1125-4$

Lees AM, Lees JC, Sejian V, Wallage AL, Gaughan JB (2017) Using infrared thermography as an in situ measure 1 of core body temperature in lot-fed Angus steers, Int J Biometeorol, https://doi.org/10. 1007/s00484-017-1433-y

Lindner-Cendrowska K, Błażejczyk K (2016) Impact of selected personal factors on seasonal variability of recreationist weather perceptions and preferences in Warsaw (Poland), Int J Biometeorol, https://doi. org/10.1007/s00484-016-1220-1

Lokys HL, Junk J, Krein A (2017) Short-term effects of air quality and thermal stress on non-accidental morbidity - a multivariate metaanalysis comparing indices to single measures, Int J Biometeorol, https://doi.org/10.1007/s00484-017-1326-0

Perkins DR (2016) Using synoptic weather types to predict visitor attendance at Atlanta and Indianapolis zoological parks, Int J Biometeorol, https://doi.org/10.1007/s00484-016-1142-y.

Sheridan SC, Allen MJ (2017) Sixty years of the International Journal of Biometeorology. Int J Biometeorol 61(1):3-10. https://doi.org/10. 1007/s00484-017-1366-5

Sinkalu VO, Ayo JO (2016) Combined effects of retinol, ascorbic acid and $\alpha$-tocopherol on diurnal variations in rectal temperature of Black Harco pullets subjected to heat stress, Int J Biometeorol, https://doi.org/10.1007/s00484-016-1157-4

Urban A, Kyselý J (2015) Application of spatial synoptic classification in evaluating links between heat stress and cardiovascular mortality and morbidity in Prague, Czech Republic, Int J Biometeorol, https://doi.org/10.1007/s00484-015-1055-1

Vanos J (2017) An update from the Chair of the students and new professionals Group of the International Society of Biometeorology. Int J Biometeorol 61(1):89-92. https://doi.org/10.1007/s00484-017$1388-\mathrm{z}$

Vanos JK (2015) ISB news from the Chair of the Student and New Professionals Group. Int J Biometeorol, https://doi.org/10.1007/ s00484-015-0981-2

Walikewitz N, Jänicke B, Langner M, Endlicher W (2015) Assessment of indoor heat stress variability in summer and during heat warnings: a case study using the UTCI in Berlin, Germany, Int J Biometeorol, https://doi.org/10.1007/s00484-015-1066-y

Zhao N, Cao G, Vanos JK, Vecellio DJ (2017) The effects of synoptic weather on influenza infection incidences: a retrospective study utilizing digital disease surveillance, Int J Biometeorol, https://doi.org/ 10.1007/s00484-017-1306-4 